DOI: 10.20472/LPC.2018.002.013

\author{
CORLIA VAN HEERDEN \\ University of Pretoria, South Africa, South Africa
}

\title{
THE LEGISLATIVE AND INSTITUTIONAL FRAMEWORK FOR SOUTH AFRICA'S NEW TWIN PEAKS MODEL OF FINANCIAL REGULATION
}

\begin{abstract}
:
In response to the lessons learnt from the 2008 Global Financial Crisis, South Africa has recently moved from a model of silo sectoral financial regulation to a Twin Peaks model captured in the new Financial Sector Regulation Act 9 of 2017. Notably South Africa is the first emerging market from the African continent to adopt such a refined regulatory model which is a sui generis adaptation of the model originally introduced by Michael Taylor.The South African model in fact has three peaks comprising of the central bank that is tasked with the promotion and maintenance of financial stability and the newly established Prudential Authority (tasked with systemwide prudential regulation) as well as the newly established Financial Sector Conduct Authority (tasked to oversee market conduct on a systemwide basis). It is submitted that it may be instructive from an international perspective to consider the carefully designed legal framework for the execution of the central bank's financial stability mandate that includes emergency powers to deal with systemic events and also the power to designate SIFIs. It would also be instructive to consider the objectives and functions of the Prudential Authority and Financial Sector Conduct Authority and how the legislative framework facilitates their contribution to financial stability and inter-agency cooperation.
\end{abstract}

\section{Keywords:}

Twin Peaks; central bank; financial stability

JEL Classification: E58 